\title{
Effect of Compost Mixes on Vegetative Development and Fruit Yield of Okra (Abelmoscus Esculentus)
}

\author{
Adebayo A. G., Shokalu A. O and Akintoye H. A \\ National Horticultural Research Institute, Ibadan
}

\begin{abstract}
Effects of different compost mixes at 10tons ha ${ }^{-1}$ were studied on okra in 2009 to 2010 planting season. The experiment was a randomized complete block design $(R C B D)$ with three replicates. Data collected were averaged over the two trials before being subjected to statistical analysis of variance and significant means compared using Duncan's Multiple Range Test. Nutrient analyses indicated that Tithonia compost (Th2pm) performed best followed by Chromonela compost (Ch3pm) and celosia compost (Ce3pm). Okra planted with Tithonia compost (Th2pm), cassava peel compost (Ca2pm) and elephant compost (Eg2pm) similarly had higher plant height. Cassava peel compost (Ca3pm), elephant grass compost (Eg2pm), cassava peel compost (Ca2pm) and elephant grass compost (Eg3pm) significantly had higher and similar effect on stem girth of okra, while okra planted with cassava peel compost(Ca2pm) and elephant grass compost(Eg2pm) significantly had higher number of leaves throughout the growing period. Okra planted with cassava peel compost (Ca2pm) significantly had higher number of fruit and fruit weight than other compost mixes.
\end{abstract}

Key Words - Compost, fertilizers, growth, organic manure, fruit yield and okra

\section{Introduction}

Okra, (Abelmoschus esculentus (L) Moench) commonly referred to as ladies finger or gombo belongs to the family Malvaceae (Brouk, 1975). It is consumed throughout Nigeria (Chriso and Onuh (2005); Katung and Kashina (2005),and ranked third in production, after tomato and onion (Grubben, 1997). The economic importance of okra cannot be overemphasized. It contains carbohydrate, proteins and vitamin $\mathrm{C}$ in large quantities (Adeboye and Oputa, 1996). When cooked, okra pod contains approximately $86.1 \%$ water, $2.2 \%$ protein, 0.25 fats, $9.7 \%$ carbohydrate, $1.0 \%$ fibre and $0.8 \%$ ash (Knot and Deanon, 1987, Purseglove, 1992, Uganda Export Promotion Board- UEPB, 2006).

Okra thrives naturally in the low land rainforest soils, high in moisture and temperature. Nitrogen fertilizers are often recommend in areas where peasant farmers are engaged almost solely in the production of this crop, because it is supposed to be the single element that often limit yield due to its heavy loss through leaching during the torrential rainfall in the low- land rainforest soils (Aduayi, 1980). Fertilizer recommendation varies from place to place due to environmental factors including soil factors. For Northern Nigeria, Majambu et al (1986), Ahmed and Tullock-Reid (1980) and FAO (1992) recommended 100kg Nha ${ }^{-1}, 30 \mathrm{~kg} \mathrm{P}_{2} \mathrm{O}_{5} \mathrm{ha}^{-1}$ and $40 \mathrm{~kg} \mathrm{~K}_{2} \mathrm{O} \mathrm{ha}^{-1}$. In the South-western part where the experiments were conducted, $80 \mathrm{~kg} \mathrm{Nha}^{-1}$ have been found (Babatola, 2006) to aid both growth and yield parameters.

Higher yields are needed for all crops to meet the demand of ever increasing world population, and vegetables are no exceptions. The potential yield of a crop can only be realized through a proper integration of crop variety, climate, soil and management. Shifting cultivation which has been the major system practiced by farmers in the past to restore fertility of the soil cannot be practiced as a result of pressure on the available productive land arising from population increase and land tenure system. Alternative to this is the use of fertilizer to maintain soil fertility under continuous land cultivation. The use of inorganic fertilizers in crop production is often seen as the panacea for nutrient losses. This is so because nutrients are immediately available to the plants, but the application of mineral fertilizer has its own demerits and these includes soil acidification, nutrient imbalance and trace element deficiencies, especially $\mathrm{Mn}$ and $\mathrm{Zn}$ (Asadu, 2004). Heavy application of inorganic fertilizers can also build up toxic concentrations of salts in the soil, and more so, the cost of purchasing inorganic fertilizers may be beyond the reach of farmers.

In Nigeria as in many developing economy, government economic policy of deregulation has resulted in price increase of agricultural input produced locally or imported, and this includes mineral fertilizer. This and other factors mentioned earlier now forces farmers to look inward for cheaper ways of increasing soil productivity through addition of locally produced organic fertilizers such as compost.

Composts are soil like amendment made from plant and animal remains. It is of more importance than inorganic fertilizer because it consists of relatively stable decomposed materials resulting from accelerated biological degradation of organic matter under controlled aerobic conditions (Storey, 1995; Epstein 1997). The advantages of compost fertilizer in crop production includes ready availability of materials for their preparation, gradual release of nutrients without being wasted through leaching, increased soil drainage, aeration, water 
holding capacity, nutrient holding capacity and being environmentally friendly has made compost application popular among farmers.

However effectiveness of compost depends primarily on source and type of organic material, method of composting and compost maturity. Mature compost provides a stabilized form of organic matter and has the potential to enhance nutrient release in the soil more than the raw organic wastes (Adediran et al (2003). However this varies with type and composition of organic materials.

This study was therefore aimed at evaluating the effectiveness of locally available organic soil amendments in vegetative development and fruit yield of okra.

\section{Materials And Methods}

Field experiments were conducted at National Horticultural research Institute (NIHORT) $7^{0} 25^{\prime \prime} \mathrm{N}$ and $3^{0} 52$ "'E, Ibadan, Nigeria between 2009 and 2010 cropping season. Ibadan lies in the derived savanna zone of Southwest Nigeria. The area has a bimodal rainfall distribution, which peaks in June/July and September. The early rain occurs between late march/early April and ends in July while the late rain occurs from August/September to November. There is a characteristic dry spell in August before the commencement of late rains. The dry season is from November to March, the annual rainfall is about $1280 \mathrm{~mm}$. Annual temperature at the location ranges from an average minimum of 24.8 and $24.4^{\circ} \mathrm{C}$ for 2009 and 2010 respectively to a maximum of $29.0^{\circ} \mathrm{C}$ in 2009 and $28.6^{\circ} \mathrm{C}$ in 2010 respectively.

The compost treatments which consisted of various plant materials composted with poultry manure on dry weight basis were: 1: Young shoot of Tithonia diversifolia/cured poultry manure (Th2pm 2:1), 2: Young shoot of Chromonela odorata / poultry manure(Ch2pm 3:1), 3: Flower heads of Celosia cristata / poultry manure (Ce2pm 2:1), 4: Elephant (Panicum maximum) grass / poultry manure (Eg2pm 2:1), 5: Cassava (Manihot esculentum) peels/ poultry manure compost (Ca3pm 3:1), 6: Cassava peels /poultry manure (Ca2pm 2:1), 7: Young shoot of Tithonia diversifolia/ cured poultry manure (Th2pm 3:1),8: Elephant grass / poultry manure compost $(\mathrm{Eg} 3 \mathrm{pm}$ 3:1), 9: cow dung $(\mathrm{Cd}), 10$ : Poultry manure $(\mathrm{Pm})$ and $\mathrm{Control}(\mathrm{Ct})$. The compost was prepared using Passively Aerated Composting Technique in a plastic pot as applied by Adediran et al, (2003) and analysed after maturity by standard procedures (Table 2). 10 tons per hectare (4kg per plot) of each material were mixed thoroughly with each plot of size $4 \mathrm{~m}^{2}$, two weeks before planting.

Planting was done at a spacing of $50 \mathrm{~cm} \times 50 \mathrm{~cm}$. Four seeds of okra (Clemson spineless) were planted per stand but later thinned to one seedling per stand to give twenty five (25) plant stands per plot at two weeks after planting. The experiments were arranged in a randomized complete block design (RCBD) and replicated three times.

Four plants per plot were randomly selected in the middle rows and tagged for data collection. Data on growth parameters (Plant height, stem girth and number of leaves) were taken at fifteen days interval on the tagged plants from 3 weeks after planting (WAP). Marketable fruits were harvested nine days after first flowering and subsequent harvest were carried out at four days interval. The weight and number of the harvested fruits were recorded as the fruit yield of okra per plant. Dry weight of shoot and root were recorded at final harvest when plants were uprooted, separated into roots and shoot and dried in an oven at $75^{\circ} \mathrm{C}$ for 48 hours. Data collected were averaged over the two trials before being subjected to statistical analysis of variance and significant means compared using Duncans Multiple Range Test at $\mathrm{p}<0.05$ confident level. (SAS Institute 1999).

\section{Results}

Pre - field soil analysis: The results of the physical and chemical analysis of the soil used for the trials before seeding were mostly sandy $\left(750 \mathrm{mg} \mathrm{g}^{-1}\right)$ loam $\left(150 \mathrm{mg} \mathrm{g}^{-1}\right)$ in texture with $\mathrm{pH}$ of 7.5 . Total nitrogen was $1.3 \mathrm{~g} \mathrm{~kg}^{-}$ ${ }^{1}, 0.13 \mathrm{~g} \mathrm{c} \mathrm{mol} \mathrm{kg}^{-1} \mathrm{~K}$, while available $\mathrm{P}$ was $8.05 \mathrm{mg} \mathrm{kg}^{-1}$, indicating that the quantities of these nutrients were inadequate for optimum plant growth. The results agrees with the observation of Aduayi et al (2002) that most Nigerian soils are deficient in nitrogen, phosphorus and potassium, where for this elements less than $1.5 \mathrm{~g} \mathrm{~kg}^{-1}$. Total $\mathrm{N}$, less than $8 \mathrm{mg} \mathrm{kg}^{-1}$ (Bray- 1-P) and less than $0.20 \mathrm{c} \mathrm{mol} \mathrm{kg}^{-1} \mathrm{~K}$ are considered respectively to be below critical level. Similarly, the exchangeable acidity $\left(\mathrm{H}^{+}\right)$of $0.05 \mathrm{c} \mathrm{mol} \mathrm{kg}^{-1}$ and organic carbon of $8.5 \mathrm{mg} \mathrm{g}^{-1}$ are also poor (Aduayi et al 2002)

Compost analysis: The nutrient concentrations of major organic materials used for the compost are shown in Table 2. The results indicated that there are differences in nutrient composition of the compost mixes. The chemical components of the different compost mixes showed that Tithonia diversifolia/Poultry manure (Th2pm 2:1) had higher Nitrogen (1.34\%) magnesium $(135.22 \mathrm{mg} / 100 \mathrm{~g})$ and iron $(0.28 \mathrm{mg} / 100 \mathrm{~g})\}$ followed by Chromonela odorata /poultry manure (Ch3pm 3:1) and celosia cristata/poultry manure (Ce3pm 3:1) both of which gave similar nutrient contents while cassava peel /poultry manure (Ca2pm 2:1) and elephant grass/poultry manure (Eg2pm 2:1) had similar nutrient content but ranked third. However in terms of trace elements content, tithonia diversifolia/poultry manure (Th2pm 2:1) had the highest content followed by celosia odoratal poultry 
manure (Ce3pm 3:1) while elephant grass/ poultry manure came third in terms of ranking. The $\mathrm{C}: \mathrm{N}$ ratio ranged from 15: 1 to $41: 1$.

Vegetative development of okra: Results indicated that vegetative development of okra were significantly $(\mathrm{P}<0.05$ ) influenced by compost treatments (Table 2). Okra treated with compost material made from tithonia diversifolia/poultry manure (Th2pm 2:1), cassava peel/poultry manure (Ca2pm 2:1) and elephant grass/poultry manure (Eg2pm 2:1) compost similarly had higher plant height. Cassava peel/poultry manure (Ca2pm 2:1), elephant grass/poultry manure (Eg2pm 2:1) compost, cassava peel/poultry manure(3:1) and elephant grass /poultry manure(Eg3pm 3:1) composts significantly had higher and similar effects on stem girth of okra, their performance on plant girth were followed by Tithonia diversifolia/poultry manure compost on ratio 2:1 and 3:1., while cassava peel/poultry manure(Ca2pm 2:1) and elephant grass /poultry manure(Eg2pm 2:1) compost treatments, significantly had higher number of leaves throughout the growing period. All the compost combinations performed better than all the raw organic materials used for okra production in the experiment.

Dry matter and fruit yield of okra: Compost application had significant effect $(\mathrm{P}<0.05)$ on dry matter accumulation and fruit yield of okra (Table 3). Cassava peel/poultry manure compost (Ca2pm 2:1), elephant grass/ poultry manure (Eg2pm 2:1) and elephant grass/ poultry manure (Eg3pm 3:1) significantly had higher root and shoot dry weight, these were followed in order of performance by elephant grass/ poultry manure (3:1) and Tithonia diversifolia/poultry manure (Th3pm 3:1). Fruit yield of okro was in the order: elephant grass

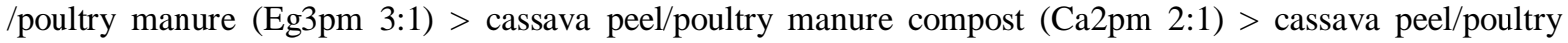
manure $(\mathrm{Ca} 3 \mathrm{pm} \mathrm{3:1)}>$ elephant grass/ poultry manure (Eg2pm 2:1), although, elephant grass /poultry manure (Eg3pm 3:1) was not statistically different from cassava peel/poultry manure compost (Ca2pm 2:1) in terms of fruit weight. Table 4 also indicated that most of the compost treatment had higher number of fruits and fruit weight than raw organic materials except Celosia cristata/poultry manure (Ce3pm 3:1) and Chromonela odorata /poultry manure (Ch3pm 3:1) composts. Generally, application of organic amendments showed better performances than control plots.

Growth components were significantly correlated with yield parameters of okro ( $p<0.05)$, although plant height at 3 weeks after planting did not show any significant correlation with all yield parameters as well as nutrient content of composts. Furthermore, nutrient content of compost did not show any significant correlations with growth components except $\mathrm{C}: \mathrm{N}$ ratio and magnesium (Table 5).

The result of the correlation between yield components of okro and nutrient content of the compost used is presented in Table 6. Significant correlations exists $(\mathrm{P}<0.05)$ between shoot dry weight, root dry weight, number of fruits and weight of fruits respectively. However, only Fe was significantly but negatively correlated with number of fruits of okro (-0.6569). Nitrogen was negatively but not significantly correlated with the yield parameters. The C:N ratio was positively and significantly $(\mathrm{P}<0.05)$ correlated with $\mathrm{K}$ and $\mathrm{Mg}(0.7464$ and 0.7064 respectively) but not with the other parameters. The stepwise regression analysis showed that among the compost nutrients parameters that relate with the number of fruits of okro, which includes nitrogen, phosphorus, potassium, calcium, magnesium, iron and zinc accounted for about $97 \%$ of total variation due to regression. Potassium and magnesium contributed 59\%, zinc contributed 12\% and calcium contributed $18 \%$ (Table 7). Likewise, these parameters (nitrogen, phosphorus, potassium, calcium, magnesium, iron and zinc) accounted for about $92 \%$ of total variation due to regression for the fruit weight of okro as shown in Table 8. Phosphorus and Fe contributed about $51 \%$, magnesium $6 \%$ and potassium $17 \%$.

\section{Discussion}

From the results of the physical and chemical analysis of the soil used for the trial, it is obvious that the fertility status of the soil is inherently low, according to the nutrient rating for soil fertility classes in Nigeria (Obigbesan, 2000) and this implies that cropping the soil without the use of soil amendments will not be economical. Variation in nutrient composition of different compost observed in this study was similarly reported by Adebayo et al (2011) working with organic amendment and its effect on early growth of Moringa oleifera observed higher nutrient concentrations in compost prepared with same type of animal droppings but different plant residues, the nutrient composition was in the order Tithonia diversifolia compost > Chromonela odorata compost > celosia cristata compost.

The nutrient content of the compost materials is quite high as compared to the control, which makes it suitable as organic fertilizer. This is evident in the growth response obtained in this trial where compost applied plots performed better than the untreated plots as shown for number of leaves, plant height and stem girth. The result obtained from the experiment highlighted the importance of compost application on okra over nonfertilized plants in terms of vegetative growth and crop yield. The superior vegetative development recorded when plants were fertilized has proved further that crops tend to grow at their maximum potential when adequate nutrients are supplied. Control $\left(0 \mathrm{~kg} \mathrm{~N} \mathrm{ha}^{-1}\right)$ consistently recorded shorter plant height, smaller stem 
girth and lower number of leaves when compared with other levels of application. The poor development of vegetative characters observed in treatment without compost (control) further confirmed the report of Akanbi et al (2000) and Akanbi 2002, that nutrient, availability especially nitrogen determine plant vegetative growth. Generally, cassava peel/poultry manure compost $(2: 1)$ with a lower $\mathrm{N}$ than Tithonia diversifolia/poultry manure (3:1) and Chromonela odorata/poultry manure (3:1) outperformed the other compost materials in this study probably because of its $\mathrm{C}: \mathrm{N}$ ratio. The $\mathrm{C}: \mathrm{N}$ Ratio plays a crucial role in the availability of nitrogen in any organic material added to the soil. Since only Ca2pm (2:1) Th3pm (2:1) Cow dung and poultry manure had optimum carbon- nitrogen ratio of 20-30:1. This is very important in composting because of the availability of nutrients to the plants. Brinton (2000) and Chukwujindu et al., (2006) reported that composts having C:N ratio less than 20 would prevent nutrient immobilization or $\mathrm{N}$ starvation in the soil. On the other hand, C:N ratio higher than 30:1 will cause microorganisms to be immobilized (i.e., consume and make unavailable for plant uptake) soil (Miller, 2000).

Compost treatments in this experiment had higher growth and yield values than the raw organic materials (Cow dung and poultry manure). This agreed with Epstein (1997) and Storey (1995) that composts are more important than inorganic fertilizer because it consists of relatively stable decomposed materials resulting from accelerated biological degradation of organic matter under controlled aerobic conditions. The significant and positive correlation of yield components with some compost nutrient content shows the ability of these organic materials to be used as soil amendments. This has also proved that these materials can be used as sustainable alternative to artificial fertilizers, thus reducing cost of agricultural input and promote good environment.

\section{Conclusion}

It is concluded from this study that composts made from various plant residues perform better than raw organic material and are quite useful in fertilizing soil for increased soil and crop productivity, but their use will depend on result of soil test to determine nutrients situation of soils, each of the amendments is suitable for ameliorating nutrient deficiency in soils. Also, apart from cassava peel/poultry manure compost (Ca2pm 2:1) and elephant grass/ poultry manure (Eg3pm 3:1), the other composts might probably need to be improved upon by the addition of other grasses or by increasing the poultry manure ratio to improve its nutrient supply.

\section{Acknowledgement}

The authors wish to express their profound gratitude to the management of National Horticultural Research, Ibadan, Nigeria for making available the time, materials and fund used for this research.

\section{References}

[1]. Adebayo, A. G., Akintoye H. A., Olufolaji, A. O, Aina O.O., Olatunji M.T. and Shokalu A.O., 2011. Assessment of organic amendments on vegetative growth and nutrient uptake of moringa oleifera in the nursery in Asian Journal of Plant Science10 (1): 74 79

[2]. Adediran, J.A., L.B. Taiwo and Sobulo R.A., 2003. Effect of organic wastes and method of composting on compost maturity, nutrient composition of compost and yield of two vegetable crops- Journal of sustainable Agriculture Volume 22 (4) 2003.

[3]. Aduayi E.A, Chude V.O, Adebusuyi B.A and Olayiwola S.O., 2002. Fertilizer use and Management practices for crops in Nigeria. $3^{\text {rd }}$ Edition, Produced by Federal Fertilizer Ministry of Agriculture and Rural Development, Abuja. Pp

[4]. Adeboye, O.C. and Oputa, C.O., 1996.Effects of galex on growth and fruit nutrient composition of okra (Abelnurschus esculentus). Ife Journal of Agriculture, 18 ( 1 \& 2), 1-9

[5]. Ahmed, N. and Turlock-Reid, L. T., 1980. Effect of fertilizer nitrogen, phosphorus andpotassium on yield and nutrient content of okra(Abelmoscus esculentus (L) Moench.)Agro. J. 60:353-355.

[6]. Akanbi, W. B. Adediran, J. A., Togun, A. O and Sobulo R. A., 2000. Effect of organic- base Fertilizer on the growth, yield and storage life of tomato (Lycopersicon eculentum Mill) Bioscience Research Communication 12 (4): 439 - 444

[7]. Akanbi, W. B., 2002. Growth, nutrient uptake and yield of maize and okra as influenced by Compost and nitrogen fertilizer under different cropping systems. Ph. D Thesis, University of Ibadan.

[8]. Asadu, C.L.A; P.I. Ezeaku and Nnaji G.U., 2004. The soil of sub-Saharan Africa and Management needs for sustainable farming. In Badejo, M.A. and A.O. Togun, Strategies and Tactics of sustainable Agriculture in the Tropics. Volume 2, College Press, Ibadan and Enproct Consultants, Lagos. pp. 1-27.

[9]. Babatola, L. A., 2006. Effect of N.P.K. 15:15:15 on the performance and storage life of okra (Abelmoscus esculentus (L) Moench)

[10]. Brinton, W., 2000. Compost quality standards and guidelines. Final Report by Woods End Research Laboratories for the New York State Association of Recyclers. http://compost.css.cornell.edu/Brinton.pdf.

[11]. Brouk, B., 1975., Plants consumed by man, Academic Press, Academic Press, London, 479pp.

[12]. Christo, E. I. and Onuh, M. O. (2005): Influence of Plant Spacing on the Growth and Yield of Okra (Abelmoschus esculentus (L) Moench. Proceedings of the 39th Conference of the Agricultural Society of Nigeria (ASN) held at Benin, 9th - 13th October, Pp 51 53.

[13]. Chukwujindu, M.A., A. Cegun, N. Emuh and N.O. Isirmiah, 2006. Compost maturity evaluation and its significant to agriculture. Pak. J. Biol. Sci., 9: 2933-2944.

[14]. Epstein, E. 1997. The science of composting. Technomic Publishing Co., Inc., Lancaster,Pennsylvania. 487pp.

[15]. F. A. O., 1992. Report of the expert consultation on genebank standards. International Board for Plant Genetic Resources, Rome. Pp. 28

[16]. Grubben, G. H., 1999. Tropical vegetable and their Genetic Resources. Edited by Tin dall and Williams, FAO, Rome, Italy, 137pp.

[17]. Katung, M. D. and Kashina, B. D., 2005. Time of Partial Defoliation and GAS Effect on 
[18]. Growth Indices and Yield of Okra (Abelmoschus esculentus) (L) Moench. Proceedings of the 39th Annual Conference of the Agricultural Society of Nigeria (ASN) held at Benin, 9th - 13th October, Pp $210-213$

[19]. Knot, J. E and Deanon, J. R., 1987. Vegetable production in South East Asia. Philippines Press 263- 265

[20]. Majambu , I. S, and Ogunlena, V. B. 1986. Response of two okra (Abelmoschus esculentus (L)

[21]. Moench) varieties to fertilizer growth and nutrient concentration as influenced bynitrogen and phosphorus application. Fertilizer Research, 8: 297 - 306

[22]. Miller, C., 2000. Understanding Carbon - Nitrogen Ratio. Acres Bulletin. April, Vol. 30: 4-20.

[23]. Ojeniyi, S. O., 2000. Effect of goat manure on soil nutrients and okra yield in a rainforest area of Nigeria

[24]. Obigbesan, G. O., 2000. Plant mineral nutrition in Nigeria: My Experience. Agronomy in Nigeria, pp 188-194.

[25]. Purseglove, J. W. 1992. Tropical crops. Dicotyledon. Vol. 1. Longman. 719pp

[26]. Schippers, R.R. (2000). African indigenous vegetable an overview of the cultivated species, National Resources Institute (NRI), University of Greenwich, London, united Kingdom, 214pp.

[27]. Storey, B. B., J.A. McFalls, and S.H. Godfrey, 1995. The use of compost and shredded brush on right of way for erosion control; Final report. Texas transportation Institute. Texas A \&

[28]. M University System. College Station, Texas.United States Composting Council 2000.

[29]. Uganda Export Promotion Board 2006. Okra, Product profile No. 5, an http document from www.ugandaexportonline.com/docs/okra.pdf.

Table 1: Climatic conditions of the experimental site

\begin{tabular}{|c|c|c|c|c|c|c|c|c|c|c|c|c|}
\hline Year & Jan & Feb & Mar & Apr & May & Jun & Jul & Aug & Sep & Oct & Nov & Dec \\
\hline
\end{tabular}

2009

\begin{tabular}{|c|c|c|c|c|c|c|c|c|c|c|c|}
\hline Rainfall (mm) & 65.6 & 31.6 & 145.3 & 238.2 & 198.9 & 183.1 & 158.9 & 44 & 193.7 & 182.8 & 52.1 \\
\hline Min. Temp. $\left({ }^{\mathrm{O}} \mathrm{C}\right)$ & 22 & 24 & 24 & 23 & 23 & 23 & 23 & 23 & 21 & 23 & 22 \\
\hline Max Temp. $\left({ }^{\circ} \mathrm{C}\right)$ & 33 & 35 & 34 & 33 & 32 & 31 & 30 & 28 & 30 & 30 & 32 \\
\hline R. Humidity (\%) & & 88 & 89 & 89 & 88 & 88 & 91 & 90 & 90 & 89 & 87 \\
\hline
\end{tabular}

2010

\begin{tabular}{|c|c|c|c|c|c|c|c|c|c|c|}
\hline Rainfall (mm) 7.5 & 111 & 59.9 & 153.4 & 207.8 & 114.6 & 164.9 & 253 & 310.8 & 119.1 & 0.0 \\
\hline Min Temp. $\left({ }^{\circ} \mathrm{C}\right) 23$ & 24 & 25 & 25 & 24 & 23 & 23 & 23 & 23 & 24 & 24 \\
\hline Max Temp. $\left({ }^{\circ} \mathrm{C}\right) 35$ & 34 & 36 & 34 & 32 & 31 & 29 & 29 & 30 & 31 & 33 \\
\hline R. Humidity (\%) 89 & 86 & 87 & 85 & 86 & 85 & 89 & 90 & 89 & 88 & 88 \\
\hline
\end{tabular}


Table 2: Chemical properties of the compost mixes

\begin{tabular}{|c|c|c|c|c|c|c|c|c|c|}
\hline Treatment & $\mathrm{N}$ & $\mathrm{P}$ & & $\mathrm{K}$ & & $\mathrm{Ca}$ & $\mathrm{Mg}$ & & $\mathrm{Fe}$ \\
\hline Th2pm (2:1) & $1.34 \mathrm{a}$ & $321.04 \mathrm{a}$ & $736.0 \mathrm{a}$ & & $6.37 \mathrm{e}$ & $135.22 \mathrm{a}$ & $0.28 \mathrm{a}$ & $1.05 \mathrm{c}$ & \\
\hline Ch3pm (3:1) & $1.28 \mathrm{~b}$ & $334.10 \mathrm{a}$ & $722.10 b$ & $7.43 \mathrm{a}$ & $127.40 \mathrm{c}$ & $0.21 \mathrm{~d}$ & $1.02 \mathrm{~d}$ & & \\
\hline Ce2pm $\quad(2: 1)$ & $1.21 \mathrm{f}$ & $310.09 \mathrm{~b}$ & $698.86 \mathrm{~d}$ & $6.67 \mathrm{~d}$ & $130.08 b$ & $0.24 b$ & $1.08 \mathrm{a}$ & & \\
\hline Eg2pm $\quad(2: 1)$ & $1.10 \mathrm{e}$ & $305.34 \mathrm{c}$ & $744.25 \mathrm{a}$ & $5.77 \mathrm{f}$ & $121.17 \mathrm{~d}$ & $0.20 \mathrm{~d}$ & $1.05 \mathrm{c}$ & & \\
\hline Cp3pm (3:1) & $1.08 \mathrm{e}$ & $311.17 b$ & $677.47 \mathrm{e}$ & $6.97 \mathrm{c}$ & $105.45 \mathrm{~g}$ & $0.22 \mathrm{c}$ & $1.03 \mathrm{~d}$ & & \\
\hline Cp2pm $\quad(2: 1)$ & $1.24 \mathrm{c}$ & $298.87 d$ & $717.20 \mathrm{~b}$ & $7.14 b$ & $112.24 \mathrm{f}$ & $0.20 \mathrm{~d}$ & $1.06 \mathrm{~b}$ & & \\
\hline Th3pm (2:1) & $1.20 \mathrm{~d}$ & $305.12 \mathrm{c}$ & $697.47 \mathrm{e}$ & $6.47 \mathrm{e}$ & $109.35 \mathrm{~g}$ & $0.25 b$ & $1.02 \mathrm{~d}$ & & \\
\hline Eg3pm (3:1) & $1.09 \mathrm{e}$ & $312.16 b$ & $722.45 b$ & $6.39 \mathrm{e}$ & $120.17 d$ & $0.23 \mathrm{c}$ & $1.06 \mathrm{~b}$ & & \\
\hline Cow dung & $1.07 \mathrm{e}$ & $325.27 \mathrm{a}$ & $688.86 \mathrm{~d}$ & $5.75 \mathrm{f}$ & $113.66 f$ & $0.22 \mathrm{c}$ & $1.05 \mathrm{c}$ & & \\
\hline P. M & $1.18 \mathrm{~d}$ & $307.87 \mathrm{c}$ & $713.20 \mathrm{~b}$ & $6.64 \mathrm{e}$ & $117.20 \mathrm{e}$ & $0.28 \mathrm{a}$ & $1.03 \mathrm{~d}$ & & \\
\hline
\end{tabular}

Notes

1: Th2pm (2:1): Tithonia diversifolia/poultry manure, 2: Ch3pm (3:1): Chromonela odorata with poultry manure 3: Ce2pm: Celosia cristata/poultry manure $4: \mathrm{Eg} 2 \mathrm{pm}$ :Elephant grass/poultry manure 5: $\mathrm{Cp} 3 \mathrm{pm}$ (3:1) Cassava peel/poultry manure 6: Cp2pm (2:1): Cassava peel/poultry manure, 7: Th3pm (3:1) Tithonia diversifolia/poultry manure, 8: Eg3pm (3:1); Elephant grass/poultry manure, 9: Cow dung and 10: P.M: Poultry manure

Table 3: Effect of compost mixes on vegetative development of okra

\begin{tabular}{|c|c|c|c|c|c|c|c|c|c|}
\hline \multirow{2}{*}{$\begin{array}{l}\text { Treatment } \\
\text { WAP }\end{array}$} & \multirow[b]{2}{*}{3} & \multicolumn{2}{|c|}{ Plant Height $(\mathrm{cm})$} & \multicolumn{3}{|c|}{ Stem Girth $(\mathrm{cm})$} & \multicolumn{2}{|c|}{ Number of leaves } & \multirow[b]{2}{*}{7} \\
\hline & & 5 & 7 & 3 & 5 & 7 & 3 & 5 & \\
\hline Th2pm(2:1) & $20.76 a$ & $24.85 a$ & $29.19 \mathrm{a}$ & $0.67 \mathrm{a}$ & $0.77 \mathrm{a}$ & $0.85 b$ & $6.25 \mathrm{~cd}$ & $9.00 \mathrm{abc}$ & $9.88 \mathrm{abc}$ \\
\hline Ch3pm(3:1) & $19.88 \mathrm{a}$ & $23.43 \mathrm{a}$ & $26,96 \mathrm{bc}$ & $0.66 \mathrm{a}$ & $0.75 \mathrm{~d}$ & $0.75 b c$ & $6.25 \mathrm{~cd}$ & $6.25 \mathrm{de}$ & $7.50 \mathrm{de}$ \\
\hline $\mathrm{Ce} 2 \mathrm{pm}(2: 1)$ & $17.76 \mathrm{~b}$ & $18.88 \mathrm{~b}$ & $24.57 b c$ & $0.62 \mathrm{a}$ & $0.67 \mathrm{~d}$ & $0.68 \mathrm{~d}$ & $5.50 \mathrm{~d}$ & $4.75 \mathrm{e}$ & $5.00 \mathrm{e}$ \\
\hline $\mathrm{Eg} 2 \mathrm{pm}(2: 1)$ & $19.57 \mathrm{a}$ & $24.67 a$ & $30.82 a$ & $0.75 \mathrm{a}$ & $0.88 \mathrm{abc}$ & $0.91 \mathrm{a}$ & $7.00 \mathrm{bc}$ & $10.88 a$ & $12.00 \mathrm{a}$ \\
\hline Ca3pm $(3: 1)$ & $18.94 \mathrm{a}$ & $22.38 b$ & $28.07 \mathrm{~b}$ & $0.67 \mathrm{a}$ & $0.89 a b c$ & $0.93 a$ & $8.38 \mathrm{a}$ & $11.38 \mathrm{a}$ & $11.40 \mathrm{ab}$ \\
\hline $\mathrm{Ca} 2 \mathrm{pm}(2: 1)$ & $18.57 \mathrm{a}$ & $24.28 \mathrm{a}$ & $30.76 a$ & $0.72 \mathrm{a}$ & $0.96 \mathrm{a}$ & $0.97 \mathrm{a}$ & $8.01 \mathrm{ab}$ & $11.50 \mathrm{a}$ & $12.03 \mathrm{a}$ \\
\hline Th3pm(3:1) & $16.76 \mathrm{c}$ & $22.28 b$ & $27.94 b$ & $0.68 \mathrm{a}$ & $0.90 \mathrm{ab}$ & $0.90 \mathrm{ab}$ & $7.63 \mathrm{ab}$ & $11.00 \mathrm{a}$ & $11.07 \mathrm{ab}$ \\
\hline Eg3pm(3:1) & $17.32 \mathrm{~b}$ & $21.52 b$ & $26.01 b c$ & $0.71 \mathrm{a}$ & $0.88 \mathrm{abc}$ & $0.95 \mathrm{a}$ & $7.35 \mathrm{ab}$ & $9.75 \mathrm{ab}$ & $10.0 \mathrm{abc}$ \\
\hline Cow dung & $18.94 a$ & $21.59 \mathrm{~b}$ & $25.26 \mathrm{bc}$ & $0.65 \mathrm{a}$ & $0.78 b c d$ & $0.78 b c$ & $6.00 \mathrm{~cd}$ & $7.13 \mathrm{cde}$ & $9.63 \mathrm{abc}$ \\
\hline PM & $16.63 \mathrm{c}$ & $20.09 b$ & $23.38 \mathrm{c}$ & $0.65 \mathrm{a}$ & $0.75 \mathrm{~d}$ & $0.78 b c$ & $6.38 \mathrm{~cd}$ & $7.63 \mathrm{bcd}$ & $8.13 \mathrm{bcd}$ \\
\hline Control & $16.51 \mathrm{~b}$ & $20.65 \mathrm{ab}$ & $27.57 \mathrm{~b}$ & $0.64 a$ & $0.88 \mathrm{a}$ & $0.86 \mathrm{~b}$ & $7.13 b c$ & $11.25 \mathrm{a}$ & $10.5 \mathrm{abc}$ \\
\hline
\end{tabular}

Means represented by same letter along column are not significantly different.

Notes

1: Th2pm (2:1): Tithonia diversifolia/poultry manure, 2: Ch3pm (3:1): Chromonela odorata with poultry manure 3: $\operatorname{Ce} 2 \mathrm{pm}(2: 1)$ : Celosia cristata/poultry manure 4: $\operatorname{Eg} 2 \mathrm{pm}(2: 1)$ :Elephant grass/poultry manure 5: Cp3pm (3:1) Cassava peel/poultry manure 6: Cp2pm (2:1): Cassava peel/poultry manure, 7: Th3pm (3:1) Tithonia diversifolia/poultry manure, 8: Eg3pm (3:1); Elephant grass/poultry manure, 9: Cow dung and 10: PM: Poultry manure 
Table 4: Effect of compost mixes on root, shoot dry weight and fruit yield of okra

\begin{tabular}{llllll}
\hline Treatments & $\begin{array}{l}\text { RDW } \\
(\mathrm{g})\end{array}$ & $\begin{array}{l}\text { SDW } \\
(\mathrm{g})\end{array}$ & $\begin{array}{l}\text { Number } \\
\text { fruits }\end{array}$ & $\begin{array}{l}\text { of } \\
\text { fruight. } \\
(\mathrm{g})\end{array}$ \\
\hline Th2pm(2:1) & $6.25 \mathrm{c}$ & $19.25 \mathrm{~b}$ & $3.25 \mathrm{c}$ & $54.5 \mathrm{c}$ \\
Ch3pm (3:1) & $4.75 \mathrm{~cd}$ & $13.25 \mathrm{c}$ & $3.75 \mathrm{bc}$ & $43.75 \mathrm{~d}$ \\
Ce2pm (2:1) & $3.00 \mathrm{~d}$ & $9.00 \mathrm{~d}$ & $3.25 \mathrm{c}$ & $32.25 \mathrm{e}$ \\
Eg2pm(2:1) & $8.50 \mathrm{~b}$ & $24.25 \mathrm{a}$ & $4.75 \mathrm{ab}$ & $72.25 \mathrm{~b}$ \\
Ca3pm (3:1) & $6.25 \mathrm{c}$ & $18.55 \mathrm{~b}$ & $3.88 \mathrm{bc}$ & $73.00 \mathrm{~b}$ \\
Ca2pm (2:1) & $10.00 \mathrm{a}$ & $23.00 \mathrm{a}$ & $6.00 \mathrm{a}$ & $82.25 \mathrm{a}$ \\
Th3pm (3:1) & $8.00 \mathrm{ab}$ & $16.76 \mathrm{bc}$ & $4.00 \mathrm{bc}$ & $49.00 \mathrm{~d}$ \\
Eg3pm (3:1) & $9.50 \mathrm{a}$ & $19.50 \mathrm{~b}$ & $4.75 \mathrm{ab}$ & $84.00 \mathrm{a}$ \\
Cowdung & $4.75 \mathrm{~cd}$ & $12.00 \mathrm{c}$ & $3.50 \mathrm{bc}$ & $46.00 \mathrm{~d}$ \\
PM & $4.75 \mathrm{~cd}$ & $13.75 \mathrm{c}$ & $3.25 \mathrm{c}$ & $35.50 \mathrm{e}$ \\
Ct & $4.75 \mathrm{~cd}$ & $22.75 \mathrm{a}$ & $4.25 \mathrm{bc}$ & $32.25 \mathrm{e}$ \\
\hline
\end{tabular}

\section{Notes}

1: Th2pm (2:1) Tithonia diversifolia/poultry manure, 2: Ch3pm (3:1) Chromonela odorata/ poultry manure, 3 : Ce2pm (2:1) Celosia argenta/poultry manure, 4: Eg2pm (2:1) Elephant grass/poultry manure, 5: Ca3pm (3:1) Cassava peel/poultry manure, 6: Ca2pm (2:1) Cassava peel/poultry manure, 7: Th3pm (3:1) Tithonia diversifolia/poultry manure, 8: Eg3pm (3:1) Elephant grass/poultry manure, 9: Cd: Cow dung and 10: PM: Poultry manure

RDW: Root dry weight, SDW: Shoot dry weight

Table 5: Correlation between Growth and Yield Components of Okro and Nutrient Content of Compost.

\begin{tabular}{|c|c|c|c|c|c|c|c|c|c|}
\hline \multirow[t]{2}{*}{ Parameter } & \multicolumn{3}{|c|}{ Plant Height } & \multicolumn{3}{|c|}{ Stem girth } & \multicolumn{3}{|c|}{ Number of Leaves } \\
\hline & 3 & 5 & 7 & 3 & 5 & 7 & 3 & 5 & 7 \\
\hline RDW & NS & NS & $0.6512 *$ & $\begin{array}{l}0.9036^{*} \\
*\end{array}$ & $\begin{array}{l}0.8215 * \\
*\end{array}$ & $\begin{array}{l}0.8967 * \\
*\end{array}$ & 0.7031* & $0.7182 *$ & $\begin{array}{l}0.7604^{*} \\
*\end{array}$ \\
\hline SDW & NS & $\begin{array}{l}0.7704 * \\
*\end{array}$ & $\begin{array}{l}0.8029^{*} \\
*\end{array}$ & $\begin{array}{l}0.7278^{*} \\
*\end{array}$ & $\begin{array}{l}0.8230^{*} \\
*\end{array}$ & $\begin{array}{l}0.8444 * \\
*\end{array}$ & $\begin{array}{l}0.6781^{*} \\
*\end{array}$ & $\begin{array}{l}0.8865^{*} \\
*\end{array}$ & $\begin{array}{l}0.8465^{*} \\
*\end{array}$ \\
\hline $\begin{array}{l}\text { Number } \\
\text { of Fruits }\end{array}$ & NS & NS & $0.6502 *$ & $\begin{array}{l}0.7545^{*} \\
*\end{array}$ & $\begin{array}{l}0.8212^{*} \\
*\end{array}$ & $\begin{array}{l}0.7559 * \\
*\end{array}$ & $0.6631^{*}$ & $0.6498 *$ & $0.6489 *$ \\
\hline $\begin{array}{l}\text { Weight of } \\
\text { Fruits }\end{array}$ & NS & NS & $0.5953^{*}$ & $\begin{array}{l}0.8428 * \\
*\end{array}$ & $0.6915^{*}$ & $\begin{array}{l}0.8301 * \\
*\end{array}$ & $0.6768^{*}$ & $0.5879 *$ & $0.6642 *$ \\
\hline C:N Ratio & NS & $\begin{array}{l}0.7982 * \\
*\end{array}$ & & & & & & & \\
\hline $\mathrm{Mg}$ & NS & & & & $-0.6664 *$ & & $-0.7352 *$ & & \\
\hline $\mathrm{N}$ & NS & & & & & & & & \\
\hline $\mathrm{P}$ & NS & & & & & & & & \\
\hline $\mathrm{K}$ & NS & & & & & & & & \\
\hline $\mathrm{Ca}$ & NS & & & & & & & & \\
\hline $\mathrm{Fe}$ & NS & & & & & & & & \\
\hline $\mathrm{Zn}$ & NS & & & & & & & & \\
\hline
\end{tabular}


Table 6: Correlation between Yield Components and Nutrient Content of Compost.

\begin{tabular}{|c|c|c|c|c|c|c|c|}
\hline Parameter & $\begin{array}{l}\text { Shoot } \\
\mathrm{dw}\end{array}$ & root dw & $\begin{array}{l}\text { Number of } \\
\text { Fruits }\end{array}$ & $\begin{array}{l}\text { Weight of } \\
\text { Fruits }\end{array}$ & $\mathrm{N}$ & $\mathrm{Mg}$ & $\begin{array}{l}\text { C:N } \\
\text { Ratio }\end{array}$ \\
\hline Shoot dw & & $0.7157 * *$ & $0.7245 * *$ & $0.6054^{*}$ & $\begin{array}{l}- \\
0.0761\end{array}$ & & \\
\hline $\begin{array}{l}\text { Number of } \\
\text { Fruits }\end{array}$ & $0.7245 * *$ & $0.8202 * *$ & & $0.7255^{* *}$ & $-\overline{0.1452}$ & & \\
\hline $\begin{array}{l}\text { Weight of } \\
\text { Fruits } \\
\mathrm{Fe}\end{array}$ & $0.6055^{*}$ & $0.8753 * *$ & $\begin{array}{l}0.7255^{* *} \\
-0.6569 *\end{array}$ & & $\begin{array}{l}- \\
0.3231\end{array}$ & & \\
\hline K & & & & & & $0.6144 *$ & $0.7464 *$ \\
\hline $\mathrm{Mg}$ & & & & & & & $0.7064 *$ \\
\hline
\end{tabular}

Table 7: Step wise regression through Backward Elimination for Number of Fruits of Okro

\begin{tabular}{|c|c|}
\hline REGRESSION EQUATION & R2 PARAMETER \\
\hline $\mathrm{NF}=-41.88+2.7 \mathrm{~N}+0.004 \mathrm{P}+0.03 \mathrm{~K}+0.39 \mathrm{Ca}-0.11 \mathrm{Mg}-9.43 \mathrm{Fe}+28.6 \mathrm{Zn}$ & $0.9661--$ \\
\hline $\mathrm{NF}=-38.88+2.6 \mathrm{~N}+0.03 \mathrm{~K}+0.39 \mathrm{Ca}-0.1 \mathrm{Mg}-10.07 \mathrm{Fe}+27.88 \mathrm{Zn}$ & $0.9661 \mathrm{P}$ \\
\hline $\mathrm{NF}=-40.34+0.03 \mathrm{~K}+0.63 \mathrm{Ca}-0.09 \mathrm{Mg}-7.7 \mathrm{Fe}+27.37 \mathrm{Zn}$ & $0.9436 \mathrm{~N}$ \\
\hline $\mathrm{NF}=48.42+0.04 \mathrm{~K}+0.73 \mathrm{Ca}-0.10 \mathrm{Mg}+31.63 \mathrm{Zn}$ & $0.8922 \mathrm{Fe}$ \\
\hline $\mathrm{NF}=-32.63+0.04 \mathrm{~K}-0.10 \mathrm{Mg}+20.99 \mathrm{Zn}$ & $0.7094 \mathrm{Ca}$ \\
\hline $\mathrm{NF}=-16.33+0.05 \mathrm{~K}-0.11 \mathrm{Mg}$ & $0.5919 \mathrm{Zn}$ \\
\hline
\end{tabular}

Table 8: Step wise regression through Backward Elimination for Weight of Fruits of Okro

PARAMETER

REGRESSION EQUATION R2

REMOVED

\begin{tabular}{|c|c|c|c|}
\hline $\begin{array}{r}\mathrm{WF}=2043-147.13 \mathrm{~N}-3.79 \mathrm{P}-2.07 \mathrm{~K}+11.51 \mathrm{Ca}+7.52 \mathrm{Mg}-691.62 \mathrm{Fe}+50.63 \mathrm{Zn} 0.9235 \\
\mathrm{WF}=2187-151.33 \mathrm{~N}-3.95 \mathrm{P}-2.17 \mathrm{~K}+11.18 \mathrm{Ca}+7.87 \mathrm{Mg}-720.5 \mathrm{Fe} 0.9230 \\
\mathrm{WF}=2196-88.25 \mathrm{~N}-3.78 \mathrm{P}-2.15 \mathrm{~K}+7.33 \mathrm{Mg}-769.52 \mathrm{Fe} 0.8657 \\
\mathrm{WF}=1738-3.08 \mathrm{P}-1.65 \mathrm{~K}+5.33 \mathrm{Mg}-714.24 \mathrm{Fe} \\
\mathrm{WF}=389-1.02 \mathrm{P}+0.61 \mathrm{Mg}-354.01 \mathrm{Fe} 0.5779 \\
\mathrm{WF}=368-0.76 \mathrm{P}-301.68 \mathrm{Fe}\end{array}$ & 0.7519 & $\begin{array}{l}-- \\
\mathrm{Zn} \\
\mathrm{Ca}\end{array}$ & $\mathrm{N}$ \\
\hline
\end{tabular}

